M. I. Zveryakov, Corr. Member of NAS of Ukraine, Dr. Sc. (Econ.), Prof., orcid.org/0000-0003-0039-5068, O. Ye. Patlatoi, Cand. Sc. (Econ.), orcid.org/0000-0002-2093-8034
Odessa National Economic University, Odessa, Ukraine, email: rector@oneu.edu.ua; alexander.patlatoy@gmail.com

\title{
INNOVATION DEVELOPMENT OF TRANSITION COUNTRIES IN THE CONTEXT OF THEIR PARTICIPATION IN GLOBAL VALUE CHAINS
}

Purpose. The analysis of participation of certain countries, that either have experienced or are undergoing market transformation, in global value chains in relation to the level of innovative development of their economies.

Methodology. The systemic-genetic and evolutionary approach made it possible to identify the economic substance of value chains and their specifics at the present stage of globalization. Economic and statistical methods, including elements of regression and graphical analysis, made it possible to group transition countries according to the level of their economic and innovation development, as well as the pattern of their participation in global value chains.

Findings. It has been revealed that in the "core" countries, the economic growth is largely determined by investment in innovations, while for transition economies this dependence is much weaker. On the one hand, some of the transition countries (including Ukraine) have inefficient national innovation systems with low returns on R\&D investments, and, on the other hand, some countries, that have experienced post-socialist transformation and joined the European Union, demonstrate relative economic success based on imported technologies brought up by the transnational capital. The vast majority of such countries has a low share of domestic value added in exports, while the EU "core", which occupies higher positions in global value chains, on the contrary, shows a high share of domestic value added in exports, a significant share of high-tech exports in gross exports, along with higher GDP per capita.

Originality. The concept of global value chains (GVC) has been applied to study transition economies, firstly, in connection with the level of their innovation development, secondly, taking into account their historical specifics, and thirdly, in the context of the current stage of development of the global economy. This made it possible to identify the different ways for integration of transition countries into the GVC: from the imitation of the advanced economies' patterns (through enhancing the high-tech international specialization based on the national capital) to the assembling of exports, based on foreign investments and technologies, with low domestic added value.

Practical value. The analysis of different options for including transition economies in global value chains provides a theoretical basis for the formation of strategic guidelines for the development of the Ukrainian economy. The proposals formulated by authors are aimed at strengthening the position of the national economy in global value chains, and in the long run at promotion of production of domestic value added based on the technological results of national and regional innovation systems.

Keywords: global value chains, transition countries, innovation development, core and periphery, high-tech exports

Introduction. Modern economic literature emphasizes that a key factor in sustainable economic growth is a developed industrial system, functioning and continuous transformation of which is based on technological innovation. As a rule, countries with powerful and efficient national innovation systems form a "core" of the global economic system, specializing in industries that generate a high share of added value, while peripheral countries usually focus on the resource-oriented industries or, in the best-case scenario, on the assembly of finished medium and high-tech products from components manufactured in the core countries. Such a division of labor is being constantly reproduced along with production of the aggregate world product, and the countries of the periphery can break out of this vicious circle only through sound industrial policies (following the example of a number of East Asian countries).

Literature review. The term "commodity chain" was introduced by T. Hopkins and E. Wallerstein as an important concept of the world-system approach and was understood as a complex of interconnected processes of added value creation at all stages of production on a global scale. According to these authors, the process of capitalist development is largely uneven, being the result of interaction of the global core and periphery. In the countries of the periphery, the majority of population is "structurally external to the capitalist world system", but becomes strongly integrated into it; the labor process in the peripheral territories is formed "into specific production chains feeding toward an output of a few kinds of products"; workers (population) including simple commodity producers, are actively involved in the capital-labor relation-

(C) Zveryakov M. I., Patlatoi O. Ye., 2020 ship, in the course of which the necessary labor time is being reduced, so the surplus labor time is set too high; as a result of inequivalent exchange, a part of the surplus value created in peripheral countries is transferred to the core countries. The reproduction of capital on the world periphery, including expanded reproduction, is carried out in primitive forms and is not accompanied by technological transformations and the growth of the technical composition of capital. In their later work, the authors note that in the peripheral segments of commodity chains the labor is remunerated under the conditions of its very low bargaining power [1].

Following the authors of this conception, some modern researchers recognize that in the course of global economic development economic relations between the core, semi-periphery and the periphery are continuously reproduced. The attention is paid to the importance of analyzing the government participation in building up the commodity chains, the relationship between the dynamics of these chains and stratification of the world-economy, as well as to the way "how "upgrading" trajectories might permit countries to improve their relative position" in the global economy [2].

Some recent publications emphasize the possible challenges for global value chains from the emerging Industry 4.0. Greater use of robotic systems and development of 3-D printing might reduce GVC and localize manufacturing activities closer to the final customers [3].

The critical foundations of the global value chain theory and "core-periphery" concepts are kept by some later publications, and some authors even try to analyze the economic thought of different regions of the world as a form of reflection of the core-periphery economic relations [4]. At the same time, the concept of commodity chains is reflected in applied 
research on international marketing and logistics, and in recent years there is a synthesis of this approach with theories of spatial organization of the economy, regional studies and the concept of clusters. The latter are considered as potential generators of a high added value in global value chains [5].

However, we believe, that the excessive emphasis on the inequivalence of exchange between core and periphery in some degree overshadows the significance of the technological factor, as a key for the economic growth of leading countries. But in fact those were deindustrialization and technological primitivization that became one of the decisive factors for the integration of post-socialist countries in the global value chains as a periphery. At the same time, unlike the classical periphery, the former socialist bloc countries, as a rule, had quite powerful national innovation systems, which, however, were oriented towards the needs of planned economy. Adaptation of these systems to market conditions led in a greater or lesser degree to the involution and destruction of a number of high-tech industries, significant losses of intellectual and human capital. All the above predetermined the object and subject of the study.

The purpose of the article is to analyze the participation of certain countries that either have experienced or are undergoing market transformation, in the global value chains in relation to the level of innovative development of their economies. The main hypothesis suggests that convergence with economically developed countries requires the formation of national industrial capital based on innovative development. The practical significance lies in analyzing the successfulness of economic experience of the transformation countries in the context of Ukraine's transition to sustainable economic growth and further economic and political integration with the EU countries.

Methodology. The systemic-genetic and evolutionary approach made it possible to identify the economic substance of value chains and their specifics at the present stage of globalization. Statistical methods, including elements of regression and graphical analysis, made it possible to group transition countries according to the level of their economic and innovative development, as well as the sort of their participation in global value chains.

Results. So, more than two-thirds of the world trade is made through global value chains (GVCs), in which products cross at least one border, but usually many borders before their final assembly [6]. However, the development of GVCs today is characterized by the conflicting trends. The new stage of globalization is marked by more intense regional rather than global economic integration. And in the period before the global recession, in 1999-2007, the average annual growth rate of global GDP had been more than $3.5 \%$, while in the period 2010-2018 it was only $3 \%$ [7]. In 2007, foreign direct investment accounted for almost $5.5 \%$ of global GDP, while in 2018 it was only $1.4 \%$ [8]. In 2007, the net inflow of foreign direct investment at current prices in the world amounted to 3.1 trillion US dollars, while in 2018 it was only 1.2 trillion US dollars [8]. The share of exports of goods and services in global GDP reached $29.4 \%$ in 2017 [9], which is comparable to the pre-crisis level, while the share of high-tech exports in the total manufactured exports in the period 2008-2018 has fallen from 19.5 to $18 \%$ [10]. All this ambiguously affected the value chains.

Gross value added realized through traditional international trade on average grew more slowly than the world GDP, while the gross value added of complex value chains (when the intermediate product crosses national borders more than once) was subject to the largest fluctuations (both increasing and decreasing): in 2004, 2008, 2010, 2011, its growth (about $25,16,25,32 \%$ respectively) exceeded the relative increase in the nominal world GDP, in 2017 growth rates of GDP and added value through complex GVC were almost equal, but the complex GVC value added turned out to be the most vulnera- ble indicator compared to the traditional international trade in the recession periods: in 2009 it has fallen by $25 \%$, whilst traditional international trade and simple GVC value only by 15 and $16 \%[6]$.

Table 1 shows that the forward GVC participation during the 2000-2017 period increased for high-income countries, and decreased for middle and lower middle income countries. A similar situation is observed with backward participation, with the exception of its slight increase for the lower-middleincome countries (Table 2). Forward GVC participation means the production of an intermediate product for processing it beyond national borders, while backward participation means the use of imported raw materials and components for further processing or assembly.

As Tables 3 and 4 show, the forward and backward participation in the GVC has increased in 2000-2017 in all groups of industries; however, the 2007 level was exceeded only by the rate of forward participation in the middle-tech industries. It should be emphasized that the nature of forward and backward participation differs in industries with different technological intensity: in high-tech industries, forward participation is associated with the supply of components for assembly to countries with cheaper labor force. Many of these countries have not passed the Lewis turning point yet, so the supply of labor of former rural residents who have moved their workforce to the industrial sector is still in abundance. The growth model, based on the assembly of imported components of high-tech products, is called in common terms the "Foxconn model", by the name of a Taiwanese company, the world's largest manufacturer of microelectronics components, which locates assembly plants in different countries of the world. Such intermediate products contain a high share of added value and are the result of intensive R\&D. At the same time, forward participation in low-tech sectors is often associated with the supply of raw materials containing low added value.

In the high- and middle-tech industries, both forward and backward GVC participation are significant. In high-tech industries, complex value chains dominate: they involve multiple activities from research and development, extraction of rare metals (necessary for the production of microprocessors), to the component manufacturing, assembly of finished products and promotion, under which the subjects of labor may

Table 1

Forward GVC participation indexes by country groups (percent of GDP) [6]

\begin{tabular}{|c|c|c|c|c|c|c|c|c|c|}
\hline \multirow{2}{*}{ Income level } & \multicolumn{3}{|c|}{$\begin{array}{c}\text { GVC } \\
\text { participation }\end{array}$} & \multicolumn{3}{|c|}{$\begin{array}{l}\text { Simple } \\
\text { GVC }\end{array}$} & \multicolumn{3}{|c|}{$\begin{array}{c}\text { Complex } \\
\text { GVC }\end{array}$} \\
\hline & ङ્สิ & ڤ్̀ิ & 도 & ญั่ & ڤ్తి & ํํำ & ङ્สิ & ڤ્ণ & ำ \\
\hline High & 9.5 & 11.8 & 12.4 & 5.6 & 6.8 & 7.1 & 3.8 & 5.0 & 5.3 \\
\hline Upper middle & 11.4 & 14.1 & 10.5 & 7.2 & 8.4 & 6.4 & 4.2 & 5.6 & 4.2 \\
\hline Lower middle & 10.8 & 12.4 & 9.1 & 6.9 & 7.6 & 5.7 & 3.9 & 4.8 & 3.4 \\
\hline
\end{tabular}

Table 2

Backward GVC participation indexes by country groups (percent of final goods production) [6]

\begin{tabular}{|c|c|c|c|c|c|c|c|c|c|}
\hline \multirow{2}{*}{ Income level } & \multicolumn{3}{|c|}{$\begin{array}{c}\text { GVC } \\
\text { participation }\end{array}$} & \multicolumn{3}{|c|}{$\begin{array}{c}\text { Simple } \\
\text { GVC }\end{array}$} & \multicolumn{3}{|c|}{$\begin{array}{l}\text { Complex } \\
\text { GVC }\end{array}$} \\
\hline & ఫ્సి & હે & 독 & ఫ્సి & હ્సે & 독 & ర్సి & હ్సి & 혹 \\
\hline High & 9.3 & 11.7 & 11.8 & 5.8 & 6.8 & 6.5 & 3.5 & 4.9 & 5.3 \\
\hline Upper middle & 12.5 & 14.1 & 10.5 & 7.3 & 7.7 & 6.3 & 5.2 & 6.4 & 4.2 \\
\hline Lower middle & 11.7 & 14.2 & 11.8 & 7.9 & 9.3 & 7.6 & 3.8 & 4.8 & 4.2 \\
\hline
\end{tabular}


Table 3

Forward GVC participation indexes by industry groups (percent of value added) [6]

\begin{tabular}{|c|c|c|c|c|c|c|c|c|c|}
\hline \multirow{2}{*}{ Sector level } & \multicolumn{3}{|c|}{$\begin{array}{c}\text { GVC } \\
\text { participation }\end{array}$} & \multicolumn{3}{|c|}{$\begin{array}{c}\text { Simple } \\
\text { GVC }\end{array}$} & \multicolumn{3}{|c|}{$\begin{array}{l}\text { Complex } \\
\text { GVC }\end{array}$} \\
\hline & ֻัญ & ક્సે & 들 & ఫ્సి & હે & ํㅗำ & ఫ્సి & స్తి & 들 \\
\hline High Tech & 25.3 & 30.7 & 28.8 & 13.8 & 16.1 & 15.6 & 11.5 & 14.6 & 13.2 \\
\hline Middle Tech & 22.5 & 21.6 & 23.7 & 14.5 & 16.4 & 14.7 & 8.0 & 9.7 & 9.1 \\
\hline Low Tech & 12.4 & 15.8 & 15.3 & 7.9 & 9.9 & 9.5 & 4.5 & 5.9 & 5.8 \\
\hline Agriculture & 8.3 & 11.4 & 10.6 & 5.8 & 7.8 & 7.2 & 2.4 & 3.6 & 3.5 \\
\hline Mining & 39.9 & 54.3 & 48.3 & 25.6 & 34.5 & 29.6 & 14.3 & 19.8 & 18.8 \\
\hline
\end{tabular}

Table 4

Backward GVC participation indexes by industry groups (percent of final goods production) [6]

\begin{tabular}{|c|c|c|c|c|c|c|c|c|c|}
\hline \multirow{2}{*}{ Sector level } & \multicolumn{3}{|c|}{$\begin{array}{c}\text { GVC } \\
\text { participation }\end{array}$} & \multicolumn{3}{|c|}{$\begin{array}{l}\text { Simple } \\
\text { GVC }\end{array}$} & \multicolumn{3}{|c|}{$\begin{array}{c}\text { Complex } \\
\text { GVC }\end{array}$} \\
\hline & ఫ్సి & હ્సે & ) & ఏ્ఝి & ڤ్ & 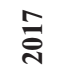 & હ્సి & ક્ปิ & 로ํ \\
\hline High Tech & 22.3 & 28.8 & 26.8 & 8.4 & 9.8 & 9.6 & 13.9 & 19.0 & 17.3 \\
\hline Middle Tech & 19.1 & 26.9 & 25.9 & 10.0 & 14.4 & 13.2 & 9.1 & 12.5 & 12.7 \\
\hline Low Tech & 16.6 & 1.8 & 20.5 & 9.9 & 11.7 & 10.5 & 6.7 & 10.1 & 10.0 \\
\hline Agriculture & 8.4 & 11.3 & 9.6 & 5.7 & 7.5 & 6.2 & 2.7 & 3.8 & 3.4 \\
\hline Mining & 10.2 & 12.1 & 11.4 & 6.5 & 6.1 & 7.6 & 3.7 & 5.9 & 3.8 \\
\hline
\end{tabular}

repeatedly cross the borders of different countries with different levels of economic development. At the same time, forward participation is an apparent priority for the extractive industries (like mining). This means that relatively underdeveloped countries supply raw materials abroad for further processing and creating added value that is many times higher than the value of resources consumed. In these cases, the simple commodity chain is an optimal economic and organizational form that provides the maximum efficiency for global capital.

So, at the present stage, global capitalism is developing through the spread of global production networks, which are becoming increasingly complicated, covering all continents and involving all countries, regardless of their level of economic development. The mode of participation of each country in the global production process is manifested in a concrete form, i.e. the global value chain, which becomes a very core of global production systems.

The preliminary analysis allows us to conclude that the political and economic power of the "core" countries is backed by their technological leadership. The USA, Western Europe, Australia, Japan, some other advanced Asian countries, etc. are traditionally considered to be the center of the world economy. A number of post-socialist states more or less successfully completed the market transformation and have become members of the European Union. However, did they manage to join the "global core" and integrate effectively into its technological structures?

Fig. 1 indicates that the most successful transitive economies managed to get closer to Spain and surpass Portugal in terms of GDP per capita adjusted for purchasing power parity (PPP), but their indicators are still below the EU and Eurozone average. At the same time, if we take the nominal values, the Portuguese GDP per capita in the amount of 23.15 thousand US dollars turned out to be almost equal to the Czech GDP (23.08 thousand US dollars), and among the investigat-

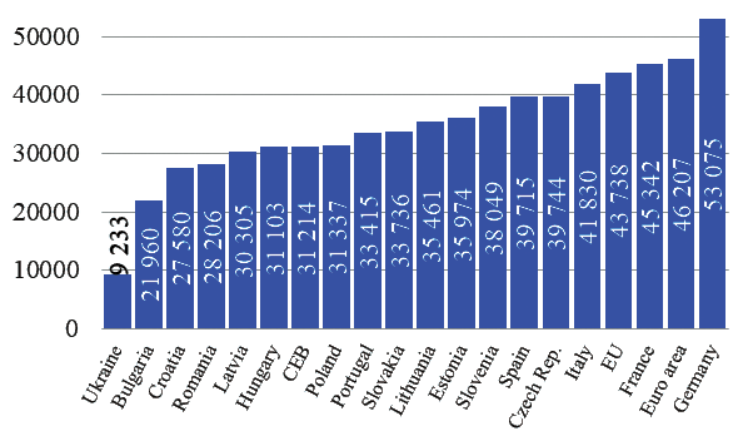

Fig. 1. GDP per capita in the selected EU countries and Ukraine in 2018, US dollars, PPP, current prices [11]

ed countries in 2018 only Slovenia (26,23 thousand dollars) has shown higher result [11].

Thus, among the transitive economies within the European Union, the Czech Republic, Slovenia, Slovakia, Estonia and Lithuania made the largest economic breakthrough, approaching the level of the South European semi-periphery. However, the average GDP PPP per capita of CEB (Central Europe and the Baltics) countries (i.e. Bulgaria, Croatia, the Czech Republic, Estonia, Hungary, Latvia, Lithuania, Poland, Romania, Slovakia, Slovenia) is $29 \%$ lower compared to the average EU level and $33 \%$ lower compared to the average Euro area level.

A number of recent research studies on polarization within the EU note that the joint neoliberal economic policy formulated by International Monetary Fund, European Commission and the European Central Bank did not contribute much to the leveling of the development of different EU regions. The Eurozone crisis in 2009 deepened the division within the EU, and the countries of Southern Europe were particularly affected by it [12]. Some authors focus on the role of insolvency of banking systems of peripheral countries in exacerbating such trends [13]. However, there are publications that consider fundamental structural imbalances as the reason why some countries are lagging behind.

According to the Polish researchers, the countries of Central and Eastern Europe, as well as the south of the EU, form the periphery and semi-periphery of the region's economy: "Central and Eastern Europe (CEE) - a group of countries with medium to low development levels, characterized by highly intense relations with their economic neighborhoods. The model of competitiveness is based on low labor costs and relatively modern exports, fueled by imported capital and technology. Southern Europe is a region characterized by a medium development level and a relatively low level of integration with the global economy. Its competitiveness is not based on low costs to the same extent as in the CEE. Its exports are less hightech intensive and more rooted in the group's own technological capabilities". It is noted though that the current development path of the Czech Republic, Estonia, Hungary and Slovenia allows these countries to become manufacturers of hightech intermediates for the core countries in the future [14].

An analysis of the factors of economic and innovation development of post-transition EU economies (the Countries of Central and Eastern Europe, namely Bulgaria, Croatia, the Czech Republic, Estonia, Hungary, Latvia, Lithuania, Poland, Romania, Slovakia, Slovenia) shows that after 2000 almost all of them have a higher share of investment in GDP than the EU average (Fig. 2). In recent years, Slovenia, Lithuania, Croatia and Poland have been approaching the average EU level of gross capital formation [15]. In the case of Slovenia this may be the result of gradual convergence with more developed countries, but, for example, for Croatia such dynamics can be a serious challenge for further economic growth.

However, economic growth is determined not only by the level of investment, but also by an increase in return on them, 
which in the long run can be provided exclusively by the development of innovation and technologies. Therefore, it is necessary to consider the factors of innovation development itself, using the two most general indicators: the number of researchers per 1,000 people (Fig. 3) and the share of R\&D expenditure in GDP.

In terms of the number of researchers in $R \& D$ per 1 thousand of population, only Slovenia and, in certain years, Estonia exceeded the average EU level. At the same time, in Romania this indicator decreased by almost a third compared to 1996 [15].

In terms of the share of gross R\&D expenditure in GDP in 2017, all the countries researched were below the average EU level (Fig. 4). In the EU countries, the R\&D-intensity of GDP in 2017 exceeded 2\%, whist, for example, in Slovakia it dropped to less than $1 \%$ compared with $2 \%$ in 1991 [16].

Thus, the economic growth in post-transition EU countries was probably not based on internal innovation development factors. At the same time, these countries are actively participating in GVCs, including those related to the production of high-tech products.

The ultimate criteria of the effective national economic system based on innovation development are GDP per capita measured in purchasing power parity (PPP), as well as the share of high-tech exports in GDP, which determines the country's position in the global division of labor. At the same time, sustainable innovative development implies a significant

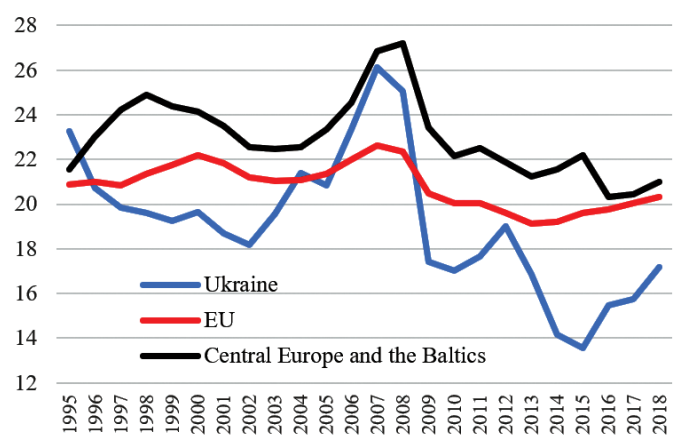

Fig. 2. Gross capital formation in the transition economies of the EU countries and Ukraine, \% of GDP, 1995-2018 [15]

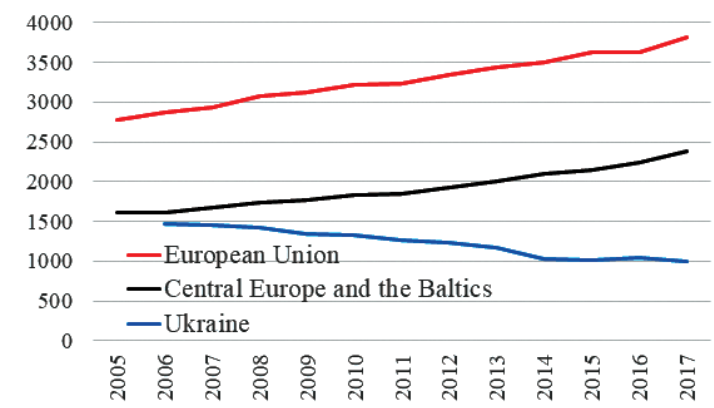

Fig. 3. The number of researchers in $R \& D$ per 1 million people, 1990-2017 [16]

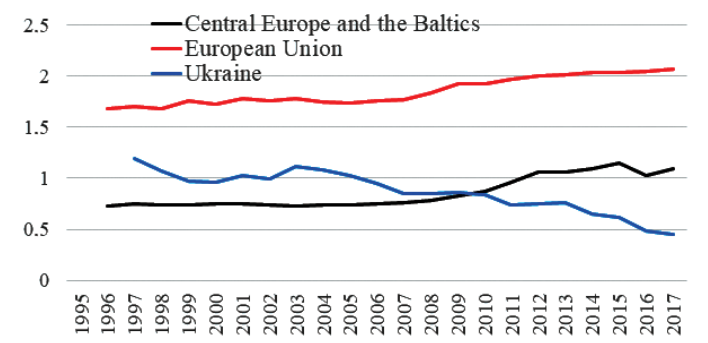

Fig. 4. Gross R\&D expenditure, \% of GDP, 1990-2017 [17] share of national value added in exports; otherwise, this more often refers only to the assembly of imported components.

The performed analysis has shown that, on average, the EU economy is characterized by the high (relative to global average) GDP per capita, a moderate share of high-tech exports in GDP (16\%), which, however, contains a high share of domestic value added (across the EU as a subject of the world trade, its exports contain more than $88 \%$ of the added value created in the participating countries). In Fig. 5, in the right upper quadrant, there are developed EU countries with a high share of high-tech exports, containing a significant part of domestic added value. It is worth noting that among the transitive economies, China and Kazakhstan belong to the same group. However, most of the Central and Eastern European countries, that experienced a post-socialist transformation and later joined the EU, are in the lower left quadrant and thus are precisely the opposite of the core EU countries. The Czech Republic is close to the average values in the compared group of countries, and Estonia exports a significant amount of hightech goods, which rely heavily on the imported components. Hungary and Slovakia export medium and relatively small volumes of high-tech products, respectively, with a very low share of domestic value added in it.

In Ukraine, the share of high-tech exports in total exports was $6.3 \%$ in 2017 and $5.4 \%$ in 2018, which is significantly lower than the global average (21.5 and $18 \%$, respectively) [10]. There is no public data on the share of domestic value added in exports. However, taking into account the weak investment activity of transnational corporations in Ukraine, the export structure, at least two-thirds of which is resource-based (in 2019, more than $40 \%$ of exports came from the agricultural sector, with $19.2 \%$ of cereals, $9.5 \%$ of vegetable/animal fats and oils; $9.7 \%$ of mineral products; $17.5 \%$ of ferrous metals, and others [19]), we can assume that the share of national value added in exports is quite high. Thus, for Ukraine, the forward GVC participation in low-tech sectors is prevailing. Accordingly, Ukraine is closest to the countries of the lower right quadrant (like Romania and Russia).

A question arises: is high R\&D expenditure necessary for a transition economy? How strong is the relationship between R\&D expenditure and economic growth? Fig. 6 shows a rather large scatter of data on transitive economies and the relatively low correlation between two indicators: GDP per capita and gross R\&D expenditure per capita. However, as soon as we add France, Germany and the EU as a whole to the chart, the coefficient of determination increases to 0.91 . This means that the economic growth of the core countries is backed by high innovation activity within their borders, while in some coun-

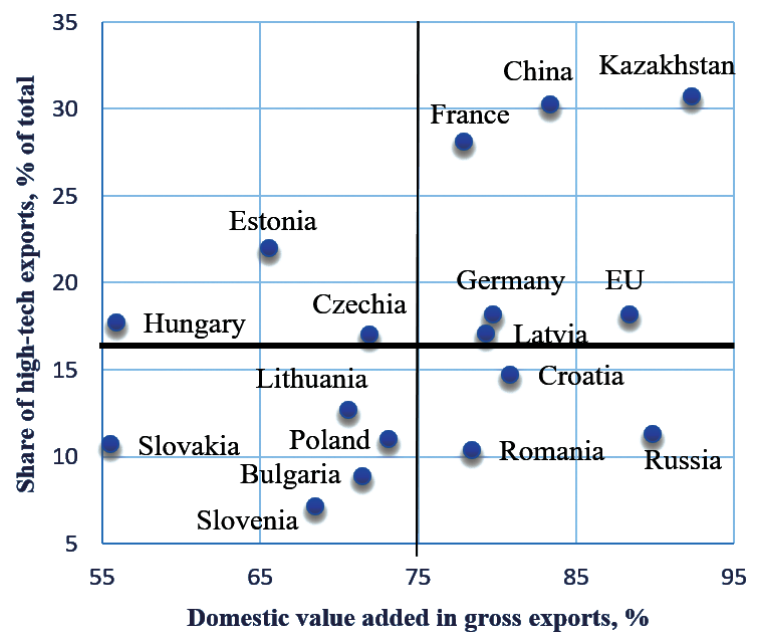

Fig. 5. Ratio between the share of high-tech exports and the share of domestic value added in selected countries, 2016 $[10,19]$ 
tries of the periphery and semi-periphery this dependence is much weaker.

To make the data more visible and include examples of developed countries of the European Union (Germany, France) and the EU as a whole, we will create a scatter diagram with a logarithmic scale (Fig. 7). Most countries are now near the trend line, but there are some anomalies, the most significant of which is Kazakhstan. Such a low indicator of R\&D expenditure in this country can be explained both by the significant inflow of ready-made technologies in the framework of economic cooperation with China and by the peculiarities/shortcomings of the national statistical system.

Latvia, Lithuania and Slovakia have a relatively high level of GDP per capita (Romania has a middle level) with relatively low gross domestic R\&D expenditure. To a large extent, the economic growth of these countries is based on the imported technologies. Thus, Slovakia and Romania are among the largest assembly hubs of transnational corporations in Europe.

However, such model of economic growth cannot be considered sustainable, since a recent analysis based on evidence from 125 countries over the period 1997-2013 indicates that such kind of participation in global value chains, as assembly of imported parts for exports, does not lead to a faster economic growth in long run, especially for relatively small countries [20]. Robotization of industrial systems, which has accelerated in developed countries after the global recession of 2008-2009, is accompanied by a reduction in foreign direct investment in many sectors, and may well lead to their reshoring [6]. Today, corporations tend to offshore some elements of planning, marketing, accounting, both relatively routine op-

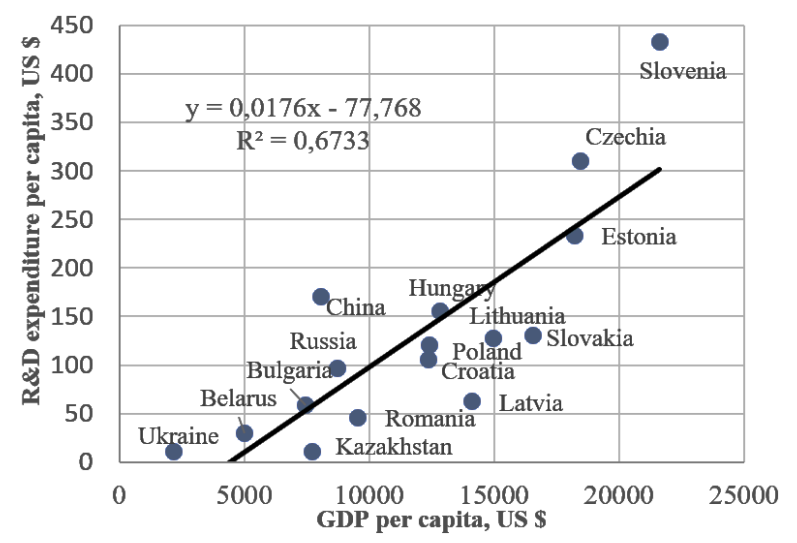

Fig. 6. Ratio between GDP per capita and R\&D per capita in selected countries, current prices, 2017 [11, 17]

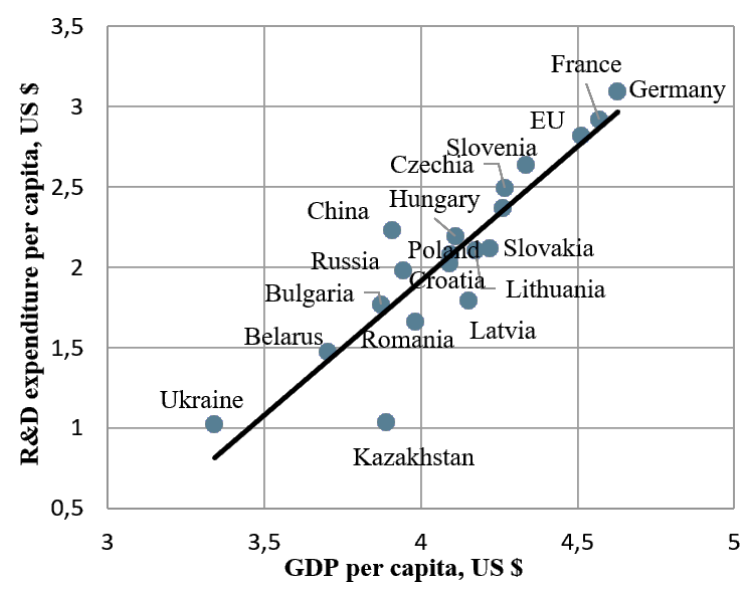

Fig. 7. Ratio between GDP per capita and $R \& D$ per capita in selected countries, current prices, 2017 (logarithmic scale) $[11,17]$ erations and fairly advanced processes within IT, rather than material production.

At the same time, there are countries in which R\&D expenditures are slightly higher in proportion to their GDP level. In the case of China, this can be explained by a systematic and focused policy aimed at creating its own industrial and innovative basis, while for Russia this may indicate the inefficiency of the national innovation system, as well as excessive militarization of the R\&D sphere.

Conclusions. The study has indicated that the degree of coverage of world economy with global value chains is restoring after the global recession of 2008-2009, although this trend has not become stable yet. The complexity of commodity chains is growing, but the countries of the global core still maintain their privileged position in appropriating the value created within these chains. And the most fundamental reason for this is the technological leadership of the core countries.

The countries of Central and Eastern Europe have carried out fairly successful market reforms and managed to attract foreign capital into relatively high-tech industries. However, the majority of them did not manage to reinforce the economic growth with an effective national innovation system. This fact hinders their convergence with the most developed EU countries. At the same time, China and Kazakhstan demonstrate strong GDP dynamics with significant high-tech exports based on domestic added value.

As long as the economy of Ukraine is quite open (according to the World Bank data, the share of exports in GDP in 2018 is $45.2 \%$, whilst the world average is below $30 \%$, [9]) and resource based, the forward participation of our country in global value chains, associated with the supply of raw materials, does not provide a sustainable economic growth.

Thus, industrial strategies in a transition economy should be based on how our country can upgrade its participation in global value chains. The strategic guideline here is the development of industries producing and exporting rather final product containing a higher share of added value compared to the intermediate. In the long run, the national industrial capital, based on the productive use of technological innovations generated by national and regional innovation systems, should become a pillar for such industries.

In order to break out of the periphery of the world economic development, in addition to general improvement of institutional conditions and formation of a favorable investment climate (which was already successfully done by the transition countries of Central and Eastern Europe in the 1990 s, but at the present stage is absolutely insufficient), Ukraine needs to:

1. Create tax and other incentives for large national capital to invest in high-tech industries.

2. Provide an isolated support for existing high-tech, export-oriented industries.

3 . In the context of increasing regionalization of the global economy, it is necessary to strengthen innovative ties with similar countries that experienced market transformation and have already joined the EU, namely, countries of Central and Eastern Europe. That would be an important step for real, rather than declarative European integration of Ukraine.

4. Since recent international surveys show the possibilities of successful integration of small and medium-sized IT firms into GVCs, this sector needs a comprehensive support, including tax and credit incentives.

References.

1. Leslie, D. (2017). Global commodity/value chains. In International Encyclopedia of Geography: People, the Earth, Environment and Technology: People, the Earth, Environment and Technology,(pp.1-10).https://doi.org/10.1002/9781118786352. wbieg0831. 
2. Bair, J. (2014). Editor's Introduction: Commodity Chains in and of the World-System. Journal of World-Systems Research, 20(1), 1-10. https://doi.org/10.5195/jwsr.2014.574.

3. Strange, R., \& Zucchella, A. (2017). Industry 4.0, global value chains and international business. Multinational Business Review, 25(3), 174-184. https://doi.org/10.1108/MBR-052017-0028.

4. Tickner, B. (2013). Core, periphery and (neo)imperialist International Relations. European Journal of International Relations, 627-646. https://doi.org/10.1177/1354066113494323.

5. De Marchi, V., Di Maria, E., \& Gereffi, G. (Eds) (2018). Local Clusters in Global Value Chains. Linking Actors and Territories Through Manufacturing and Innovation. New York: Routledge.

6. Global Value Chain Development Report 2019. Technological Innovation, Supply Chain Trade, and Workers in a Globalized World (2019). World Trade Organization. Retrieved from: http://documents.worldbank.org/curated/en/384161555079173489/pdf/ Global-Value-Chain-Development-Report-2019-Technological-Innovation-Supply-Chain-Trade-and-Workers-in-a-Globalized-World.pdf.

7. The World Bank (n.d.). GDP growth (annual \%). Retrieved from: https://data.worldbank.org/indicator/NY.GDP.MKTP. KD.ZG.

8. The World Bank (n.d.). Foreign direct investment, net in flows (\% of GDP). Foreign direct investment, net inflows (BoP, current US\$). Retrieved from: https://data.worldbank.org/indicator/ bx.klt.dinv.wd.gd.zs. $\quad$ https://data.worldbank.org/indicator/ BX.KLT.DINV.CD.WD.

9. The world Bank. Exports of goods and services (\% of GDP). Retrieved from: https://data.worldbank.org/indicator/ne.exp. gnfs.zs.

10. The World Bank (n.d.). High-technology exports (\% of manufactured exports). Retrieved from: https://data.worldbank.org/indicator/tx.val.tech.mf.zs.

11. The World Bank (n.d.). GDP per capita, PPP (current international \$). GDP per capita (current US\$). Retrieved from: https://data.worldbank.org/indicator/NY.GDP.PCAP.PP.CD. https://data.worldbank.org/indicator/NY.GDP.PCAP.CD.

12. Magone, J. L., Laffan, B., \& Schweiger, C. (Eds) (2016). Core-periphery Relations in the European Union. Power and Conflict in a Dualist Political Economy (1 $\left.{ }^{\text {st }} \mathrm{ed}\right)$. New York: Routledge. 13. Baimbridge, M., Litsios, I., Jackson, K., \& Lee, U.R. (2017). The Segmentation of Europe. Convergence or Divergence between Core and Periphery? London: Palgrave Macmillan.

14. Grodzicki, M. J., \& Geodecki, T. (2016). New dimensions of core-periphery relations in an economically integrated Europe. The role of global value chains. Eastern European Economics 54(5), 377-404. https://doi.org/10.1080/00128775.201 6.1201426 .

15. The World Bank (n.d.). Gross capital formation (\% of GDP). Retrieved from: https://data.worldbank.org/indicator/NE. GDI.TOTL.ZS.

16. The World Bank (n.d.). Researchers in $R \& D$ (per million people). Retrieved from: https://data.worldbank.org/indicator/SP.POP.SCIE.RD.P6.

17. The World Bank (n.d.). Research and development expenditure (\% of GDP). Retrieved from: https://data.worldbank.org/ indicator/gb.xpd.rsdv.gd.zs.

18. OECD (n.d.). Domestic value added in gross exports. Retrieved from: https://data.oecd.org/trade/domestic-value-added-in-gross-exports.htm.

19. State Statistics Service of Ukraine (n.d.). Commodity structure of international trade. Retrieved from: http://www.ukrstat. gov.ua/operativ/operativ2019/zd/tsztt/tsztt_u/tsztt1219_u. htm.

20. Fagerberg, J., Lundvall, B.A., \& Srholec, M. (2018). Global Value Chains, National Innovation Systems and Economic Development. The European Journal of Development Research, 3(22), 533-556. https://doi.org/10.1057/ s41287-018-0147-2.

\section{Інноваційний розвиток транзитивних країн у контексті участі у глобальних ланцюгах доданої вартості}

\author{
М.І. Звєряков, О. Є. Патлатой
}

Одеський національний економічний університет, м. Одеca, Україна, e-mail: rector@oneu.edu.ua; alexander.patlatoy@ gmail.com

Мета. Аналіз участі окремих країн, що пережили або переживають ринкову трансформацію, у глобальних ланцюжках доданої вартості у зв'язку з рівнем інноваційного розвитку їхніх економік.

Методика. Системно-генетичний та еволюційний підхід дозволив виявити економічний зміст ланцюгів доданої вартості та їх специфіку на сучасному етапі глобалізації. Економіко-статистичні методи, що включають елементи регресійного та графічного аналізу, дозволили згрупувати транзитивні країни відповідно до рівня їх економічного та інноваційного розвитку, а також характеру участі у глобальних ланцюгах доданої вартості.

Результати. Виявлено, що в країнах «ядра» економічне зростання значною мірою обумовлено інвестиціями в інновації, у той час як для транзитивних економік така залежність простежується набагато слабкіше. 3 одного боку, деякі із транзитивних країн (у тому числі Україна) мають неефективні національні інноваційні системи з низькою віддачею від інвестицій у НДДКР, з іншого боку - окремі країни, шо пережили постсоціалістичну трансформацію та приєдналися до Європейського союзу, демонструють відносні економічні успіхи, спричинені зокрема імпортованими технологіями, які прийшли разом із транснаціональним капіталом. Переважна більшість таких країн характеризується низькою часткою внутрішньої доданої вартості в експорті, тоді як «ядро» $Є С$, що займає вищі позиції у глобальних ланцюжках доданої вартості, навпаки, демонструє високу частку внутрішньої доданої вартості в експорті, значну частку високотехнологічного експорту у валовому експорті поряд із більш високим ВВП на душу населення.

Наукова новизна. Концепт глобальних ланцюжків доданої вартості був застосований для дослідження транзитивних економік, по-перше, у зв'язку з рівнем їх інноваційного розвитку, по-друге, з урахуванням їхніх конкретно-історичних особливостей, по-третє, у контексті сучасного етапу розвитку глобальної економіки. Такий підхід дав можливість ідентифікувати різні шляхи інтеграції транзитивних економік до глобальних ланцюгів доданої вартості: від імітації моделей високорозвинених економік (через заохочення високотехнологічної спеціалізації, заснованої на національному капіталі) до переважної збірки експорту з низькою внутрішньою доданою вартістю, що спирається на іноземні інвестиції й технології.

Практична значимість. Аналіз різних варіантів включення транзитивних економік у глобальні ланцюжки доданої вартості надає теоретичну основу для формування стратегічних орієнтирів розвитку економіки України. Сформульовані пропозиції спрямовані на посилення позицій національної економіки у глобальних ланцюжках доданої вартості, а в довгостроковій перспективі - на забезпечення виробництва національної доданої вартості, заснованої на технологічних результатах національної та регіональних інноваційних систем.

Ключові слова: глобальні ланцюги доданої вартості, транзитивні країни, інноваційний розвиток, ядро та периферія, високотехнологічний експорт 


\section{Инновационное развитие транзитивных стран в контексте участия в глобальных цепочках добавленной стоимости}

\section{М. И. Зверяков, А. Е. Патлатой}

Одесский национальный экономический университет, г. Одесса, Украина, e-mail: rector@oneu.edu.ua; alexander. patlatoy@gmail.com

Цель. Анализ участия отдельных стран, переживших или переживающих рыночную трансформацию, в глобальных цепочках добавленной стоимости в связи с уровнем инновационного развития их экономик.

Методика. Системно-генетический и эволюционный подход позволил выявить экономическое содержание цепочек добавленной стоимости и их специфику на современном этапе глобализации. Экономико-статистические методы, включающие элементы регрессионного и графического анализа, позволили сгруппировать транзитивные страны в соответствии с уровнем их экономического и инновационного развития, а также характером участия в глобальных цепочках добавленной стоимости.

Результаты. Выявлено, что в странах «ядра» экономический рост в значительной степени обусловлен инвестициями в инновации, в то время как для транзитивных экономик такая зависимость прослеживается намного слабее. С одной стороны, некоторые из транзитивных стран (в том числе Украина) имеют неэффективные национальные инновационные системы с низкой отдачей от инвестиций в НИОКР, з другой стороны - отдельные страны, пережившие постсоциалистическую трансформацию и присоединившиеся к Европейскому союзу, демонстрируют относительные экономические успехи, основанные на импортированных технологиях, пришедших вместе с транснациональным капиталом. Подавляющее большинство таких стран характеризуется низкой долей внутренней добавленной стоимости в экспорте, тогда как «ядро» ЕС, занимающее более высокие позиции в глобальных цепочках добавленной стоимости, напротив, демонстрирует высокую долю внутренней добавленной стоимости в экспорте, значительную долю высокотехнологического экспорта в валовом экспорте наряду с более высоким ВВП на душу населения.

Научная новизна. Концепт глобальных цепочек добавленной стоимости был применён для исследования транзитивных экономик, во-первых, в связи с уровнем их инновационного развития, во-вторых, с учётом их конкретно-исторических особенностей, в-третьих, в контексте современного этапа развития глобальной экономики. Такой подход дал возможность идентифицировать различные пути интеграции транзитивных экономик в глобальные цепочки добавленной стоимости: от имитации моделей развитых экономик (через стимулирование высокотехнологичной специализации, основанной на национальном капитале) до преимущественной сборки экспорта с низкой внутренней добавленной стоимостью, основанного на иностранных инвестициях и технологиях.

Практическая значимость. Анализ разных вариантов включения транзитивных экономик в глобальные цепочки добавленной стоимости предоставляет теоретическую основу для формирования стратегических ориентиров развития экономики Украины. Сформулированные предложения направлены на усиление позиций национальной экономики в глобальных цепочках добавленной стоимости, а в долгосрочной перспективе - на обеспечение производства национальной добавленной стоимости, основанной на технологических результатах национальной и региональных инновационных систем.

Ключевые слова: глобальные цепочки добавленной стоимости, транзитивные страны, инновационное развитие, ядро и периферия, высокотехнологический экспорт

Recommended for publication by V.M. Tarasevych, Doctor of Economic Sciences. The manuscript was submitted 14.05.19. 